\title{
Margaret McCartney: Early cancer diagnosis: how low should we go?
}

\author{
Margaret McCartney general practitioner, Glasgow
}

Harpal Kumar, chief executive of Cancer Research UK, recently lectured at the Royal College of General Practitioners' annual conference. My blood pressure rose steadily throughout.

He said GPs should ensure that $75 \%$ of our patients take up their invitations to cancer screening. He also said that the National Institute for Health and Care Excellence's new threshold for cancer risk that should trigger referral (3\%) may need to be lowered, as a recent study had found that patients at lower risk wanted to be investigated. ${ }^{1}$

But what is the "right" level of risk at which to investigate? Even if the computer tools slowly being introduced to estimate risk thresholds for symptoms are eventually shown to improve morbidity and all cause mortality, ${ }^{3}$ their use will be accompanied by harm - namely, false positives and negatives.

The front line of medicine is inexact, messy, and tempered by factors esoteric and practical: the patient who doesn't want to go into hospital no matter what, or the patient whose symptoms are $99.99 \%$ certainly not cancer but are so troubling that we want investigation. And other, non-cancer, diagnoses are often just as important.

Troubling again is the lowering of thresholds for investigation in a stressed NHS system. Without massive and immediate investment, the increased volume of patients referred at lower risk may cause longer waits for those at higher risk. This is a harm but, as yet, one that is untold.

As for research purporting to show that more people want to be investigated at lower thresholds, this is what was found. But the side effects of lowering testing thresholds were not explained to patients, and the use of time as a diagnostic tool wasn't considered as a way to sort higher risk patients from those at lower risk.

The mantra "early diagnosis" is a bit like "free money"-it sounds great, but there's a complicated catch. Patients will be short changed unless it's fairly explained. Why are we so reluctant to be upfront about downsides?

Furthermore, we don't know what a "good" screening uptake is. Even the Care Quality Commission judges general practices on uptake rates despite national screening programmes being externally run and without asking people what they choose.

I don't know whether patients want screening or not until they've been invited and had the pros and cons fairly explained. Many then decide not to have it. ${ }^{45}$ It's absurd that the harms of medicine are consistently buried under apparently good, easy news. We must start treating potential patients as people who can appreciate nuance and who need to be informed about harm.

Competing interests: I have read and understood BMJ policy on declaration of interests and declare the following interests: I'm an NHS GP partner, with income partly dependent on Quality and Outcomes Framework points. l've written two books and earn from broadcast and written freelance journalism. I'm an unpaid patron of Healthwatch. I make a monthly donation to Keep Our NHS Public. I'm a member of Medact. I'm occasionally paid for time, travel, and accommodation to give talks or have locum fees paid to allow me to give talks but never for any drug or public relations company. I was elected to the national council of the Royal College of General Practitioners in 2013 and am chair of its standing group on overdiagnosis. I have invested a small amount of money in a social enterprise, Who Made Your Pants? Provenance and peer review: Commissioned; not externally peer reviewed.

Follow Margaret on Twitter, @mgtmccartney

Banks J, Hollinghurst S, Bigwood L, Peters TJ, Walter FM, Hamilton W. Lancet Oncol 2014;15:232-40. www.thelancet.com/journals/lanonc/article/PIIS1470-2045(13)70588-6/ fulltext?rss=yes.

2 McCartney M. Cancer strategy should be led by evidence. BMJ 2015;350:h735

3 Hamilton W, Green T, Martins T, Elliott K, Rubin G, Macleod U. Evaluation of risk assessment tools for suspected cancer in general practice: a cohort study. Br J Gen Pract 2013;63:e30-6.

4 Schonberg MA, Hamel M, Davis RB, et al. Development and evaluation of a decision aid on mammography screening for women 75 years and older. JAMA Intern Med 2014;174:417-24.

5 Smith SK, Trevena L, Simpson JM, Barratt A, Nutbeam D, McCaffery KJ. A decision aid to support informed choices about bowel cancer screening among adults with low education: randomised controlled trial. BMJ 2010;341:c5370. 